WSRC-TR-2004-00096

\title{
EROSION MODELING ANALYSIS FOR SME TANK CAVITY
}

Si Y. Lee, Richard A. Dimenna, John R. Neuville, and Glenn A. Taylor

Savannah River Technology Center

Westinghouse Savannah River Company

Savannah River Site

Aiken, SC 29808

Prepared for the U.S. Department of Energy Under Contract Number DEAC09-96SR18500

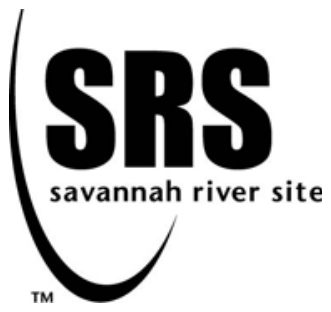


This document was prepared in conjunction with work accomplished under Contract No. DE-AC09-96SR18500 with the U. S. Department of Energy.

\section{DISCLAIMER}

This report was prepared as an account of work sponsored by an agency of the United States Government. Neither the United States Government nor any agency thereof, nor any of their employees, makes any warranty, express or implied, or assumes any legal liability or responsibility for the accuracy, completeness, or usefulness of any information, apparatus, product or process disclosed, or represents that its use would not infringe privately owned rights. Reference herein to any specific commercial product, process or service by trade name, trademark, manufacturer, or otherwise does not necessarily constitute or imply its endorsement, recommendation, or favoring by the United States Government or any agency thereof. The views and opinions of authors expressed herein do not necessarily state or reflect those of the United States Government or any agency thereof.

This report has been reproduced directly from the best available copy.

Available for sale to the public, in paper, from: U.S. Department of Commerce, National Technical Information Service, 5285 Port Royal Road, Springfield, VA 22161, phone: (800) 553-6847, fax: (703) 605-6900

email: orders@ntis.fedworld.gov

online ordering: http://www.ntis.gov/help/index.asp

Available electronically at http://www.osti.gov/bridge

Available for a processing fee to U.S. Department of Energy and its contractors, in paper, from: U.S. Department of Energy, Office of Scientific and Technical Information, P.O. Box 62, Oak Ridge, TN 37831-0062,

phone: (865)576-8401,

fax: (865)576-5728

email: $\underline{\text { reports@ adonis.osti.gov }}$ 
WSRC-TR-2004-00096

KEYWORDS:

Defense Waste Process Facility Computational Fluid Dynamics Approach

Tank Flow Model

Erosion Model

\section{Erosion Modeling Analysis For SME Tank Cavity}

Si Y. Lee, Richard A. Dimenna, John R. Neuville, and Glenn A. Taylor

SAVANNAH RIVER TECHNOLOGY CENTER

February 2004

Westinghouse Savannah River Company

Savannah River Site

Aiken, SC 29808

Prepared for the U.S. Department of Energy Under Contract Number DEAC09-96SR18500

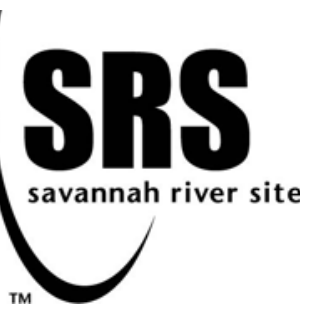


WSRC-TR-2004-00096

(This Page Intentionally Left Blank) 
This page was intentionally left blank 
WSRC-TR-2004-00096

(This Page Intentionally Left Blank) 


\section{Table of Contents}

List of Figures

List of Tables

Abstract

1. Introduction

2. Analysis Approach and Methodology

3. Results and Discussions

4. Summary and Conclusions

5. References vii

ix

1

2

4

5

13

14 
WSRC-TR-2004-00096

(This Page Intentionally Left Blank) 


\section{List of Figures}

Figure 1. Modeling geometry of the coil support structure in SME tank for the present erosion analysis

Figure 2. Three-dimensional computational meshes used for the CFD modeling calculations

Figure 3. Comparison of the predicted high wall shear indicated on the right lead-in plate (above) to the worn-away lead-in plate shown in the visual inspection photo (below) (the model predictions based on $130 \mathrm{rpm}(1.8 \mathrm{~m} / \mathrm{sec})$ and $30^{\circ}$ flow incidence)

Figure 4. Wall shear comparison of the SME/MFT coil support structures with the eroded tank bottoms for two different gap sizes between the tank bottom and the lower end of coil support under $130 \mathrm{rpm}$ agitator operation.

Figure 5. Comparison of wall shear distributions for various gap and cavity sizes under $130 \mathrm{rpm}$ agitator operation

Figure 6. Comparison of wall shear distributions between the modified tank bottom and the eroded tank bottom for $103 \mathrm{rpm}$ agitator operation

Figure 7. Vertical flow contour inside the eroded cavity region (The blue region is the downward and the red region is upward)

Figure 8. Vorticity distributions near the top plane of the eroded cavity region. 
WSRC-TR-2004-00096

(This Page Intentionally Left Blank) 


\section{List of Tables}

Table 1. Input parameters for the present calculations

Table 2. Maximum wall shears for four major erosion locations observed by the recent SME inspections and CFD modeling results for SME coil guide (0.5 in gap between tank floor and the lower end of coil support bar with flat tank bottom)...... 6

Table 3. Maximum wall shears for five major erosion locations observed by the recent

SME inspections and CFD modeling results for the existing SME coil guide $(0.5$ in gap between tank floor and the lower end of coil support bar and 0.35 in cavity depth, referring to Fig. 4)....

Table 4. Maximum wall shears at the bottoms of two different cavity sizes on the SME

tank floor and two different gap sizes for 130 rpm operating conditions 
WSRC-TR-2004-00096

(This Page Intentionally Left Blank) 


\section{Acronyms}

\section{Acronyms}

$\begin{array}{ll}\text { CFD } & \text { Computational Fluid Dynamics } \\ \text { DOE } & \text { Department of Energy } \\ \text { DWPF } & \text { Defense Waste Processing Facility } \\ \text { MFT } & \text { Melter Feed Tank } \\ \text { rpm } & \text { Rotations Per Minute } \\ \text { sg } & \text { Specific Gravity } \\ \text { SME } & \text { Slurry Mix Evaporator }\end{array}$


WSRC-TR-2003-00534

(This Page Intentionally Left Blank) 


\section{Abstract}

Previous computational work to evaluate erosion in the DWPF Slurry Mix Evaporator vessel has been extended to address the potential for the erosion to accelerate because of changes to the tank bottom profile. The same erosion mechanism identified in the previous work, abrasive erosion driven by high wall shear stress, was applied to the current evaluation.

The current work extends the previous analysis by incorporating the observed changes to the tank bottom and coil support structure in the vicinity of the coil guides. The results show that wall shear on the tank bottom is about the same magnitude as found in previous results. Shear stresses in the eroded cavities are reduced compared to those that caused the initial erosion to the extent that anticipated continued erosion of those locations is minimal. If SME operations were continued at an agitator speed of $130 \mathrm{rpm}$, the edge of the existing eroded cavities would probably smooth out, while the rate of erosion at the bottom of the cavity would decrease significantly with time. Further, reducing the agitator speed to $103 \mathrm{rpm}$ will reduce shear stresses throughout the bottom region of the tank enough to essentially preclude any significant continued erosion.

Because this report is an extension to previously documented work, most background information has been omitted. A complete discussion of the motivation for both the analysis and the modeling is provided in Lee et al., "Erosion Modeling Analysis for Modified DWPF SME Tank", WSRC-TR-2003-00534. 


\section{Introduction}

A recent visual inspection of the Slurry Mix Evaporator (SME) tank interior revealed significant areas of erosion to the tank bottom where the cooling coil restraints are located [1]. The modeled profile of the tank bottom has been updated to include an erosion area in the shape of a half section of an ellipsoid. This modification was made to the existing SME/MFT computational model to evaluate changes to erosion rates on the tank bottom.

As shown in Fig. 1, the present model is the same as that used in previous work, except that it includes an eroded cavity as observed by the visual inspection. This is basically the extension of the previous model [2] to evaluate the erosion sensitivities for different cavity sizes and gap distances because of a tilted tank floor. The model was developed to represent the flow field around each coil restraint. The cavity was modeled by locating a half-section ellipsoid 2.3 in wide and 0.35 in deep (or 2.8 in wide and 0.6 in deep for the larger cavity) on the tank bottom near the coil restraint.

In the previous work [2, 3] the principal mechanism of wear for a solids laden fluid was identified, and the solution methodology was established. The previous results showed a good comparison between the observed erosion sites and the calculated locations of high shear regions, as well as the degree of erosion and the calculated shear stress. It was noted that the loss of the leading edge of the coil guide due to the erosion damage during the SME mixing operation does not affect the erosion patterns on the tank bottom.

This report applies the same methods to the evaluation of the erosion phenomena expected in the SME, viz., by calculating the wall shear stress as the principal erosion driver. The present analysis is focused on erosion predictions for the cavity in the tank bottom.

Table 1 shows typical conditions for key operating parameters. This information will be used in the present modeling calculations, and three agitation speeds are used: $65 \mathrm{rpm}$, $103 \mathrm{rpm}$, and $130 \mathrm{rpm}$.

Table 1. Input parameters for the present calculations

\begin{tabular}{|c|c|}
\hline Parameters & Input data \\
\hline Bulk fluid specific gravity & $1.35 \mathrm{sg}$ \\
\hline Fluid viscosity & $10 \mathrm{cp}$ \\
\hline $\begin{array}{c}\text { Fluid velocity at the model boundary } \\
\text { (agitator speed) }\end{array}$ & $\begin{array}{c}0.65 \mathrm{~m} / \mathrm{sec}(65 \mathrm{rpm}), 1.3 \mathrm{~m} / \mathrm{sec}(103 \mathrm{rpm}), \text { and } \\
1.8 \mathrm{~m} / \mathrm{sec}(130 \mathrm{rpm})\end{array}$ \\
\hline
\end{tabular}




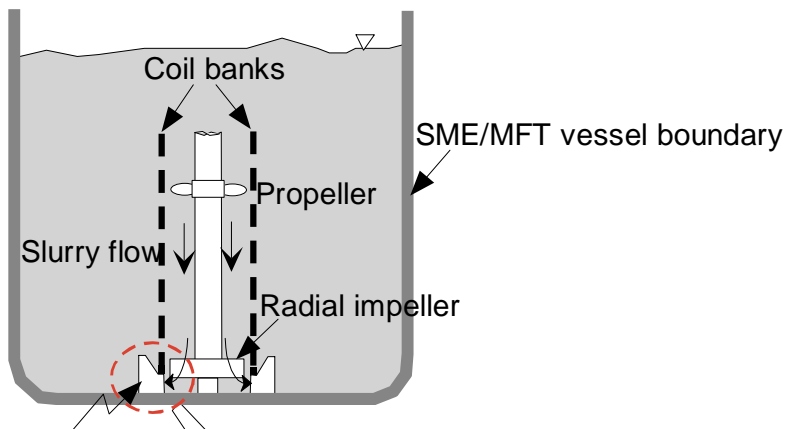

Coil guide pin (one of four pins)

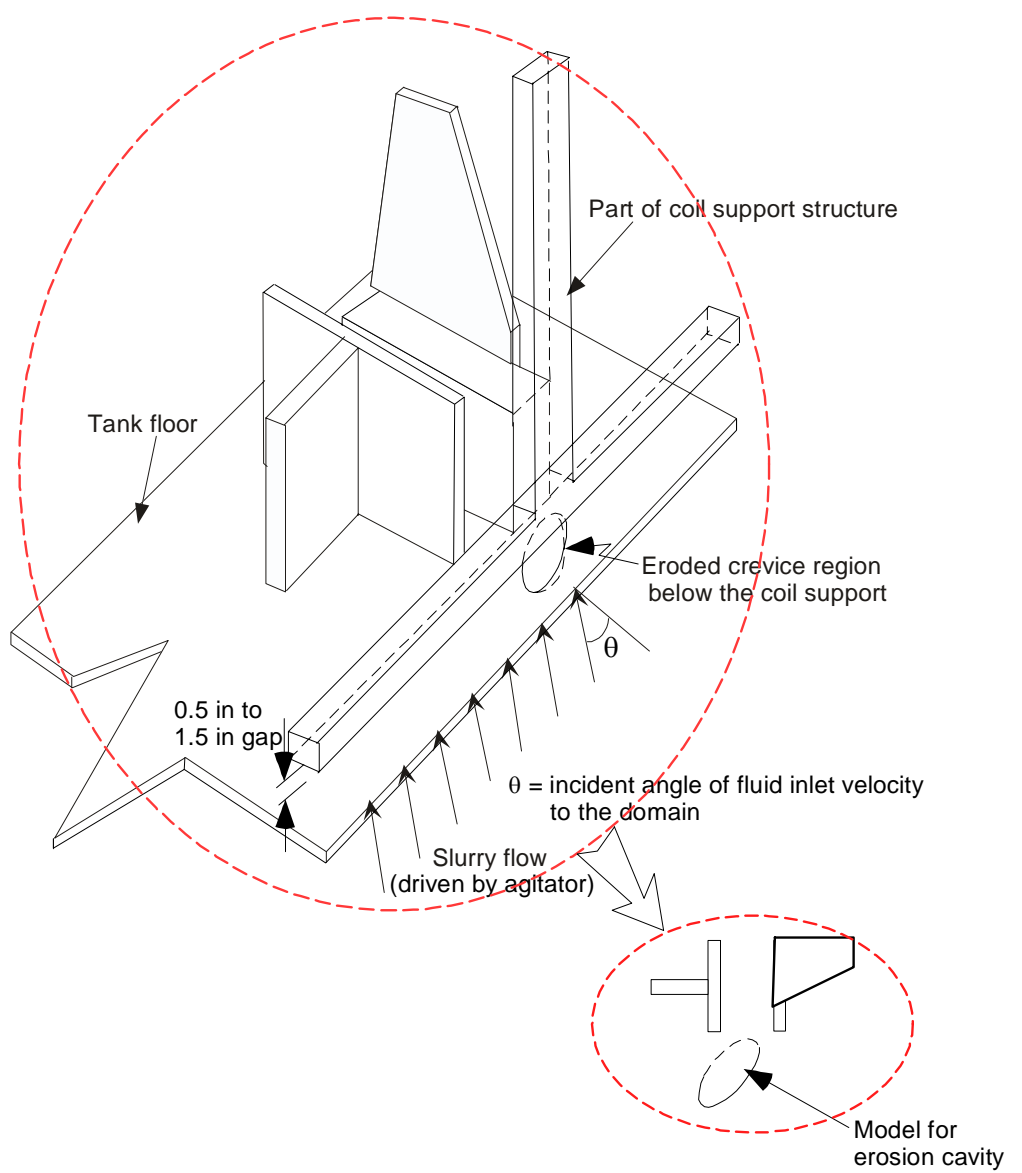

(Top view of model domain with coil support removed)

Figure 1. Modeling geometry of the coil support structure in SME tank for the present erosion analysis 


\section{Analysis Approach and Methodology}

The present analysis focuses on flow behavior in the vicinity of the coil guide and its supporting structure for the SME vessel with a tank bottom reflecting observed erosion. The CFD model is used to calculate the erosion drivers and infer the degree of erosion that would subsequently result.

Figure 2 shows the three-dimensional computational meshes and domain used for the analysis. Evaluations for three different agitator speeds were performed. In this case, there are different gap distances between the lower end of coli support and the tank bottom at four coil guide supports because of a tilted tank floor. Different cavity depths on tank floor and two gap distances were also used for sensitivtity study. The results were compared with each other, as well as with previous model results to evaluate changes to flow patterns created by the cavity on the tank bottom. This same modeling domain was used for all the calculations reported here, as well as for those reported in the previous report. In some figures, the coil support is removed from a diagram to better show shear stress patterns on the tank bottom, but this is for visualization purposes only. The coil support was included in all calculations, even if it is not shown in the figure.

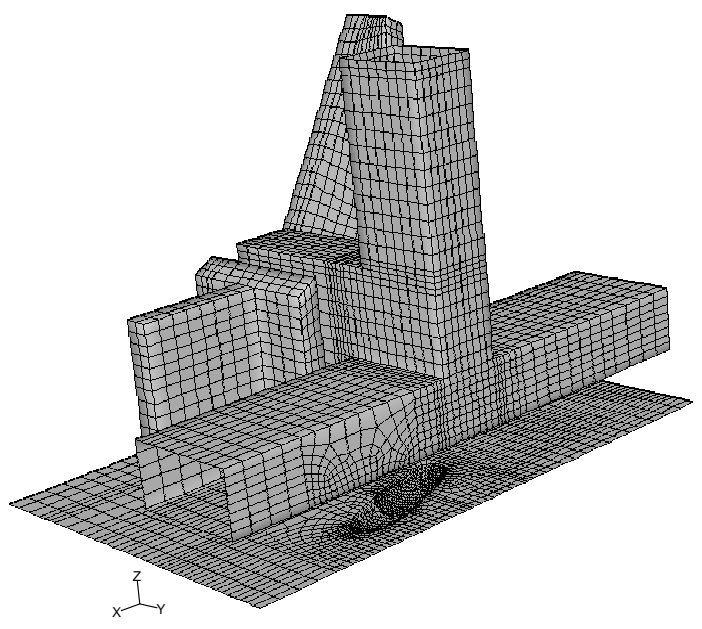

Figure 2. Three-dimensional computational meshes used for the CFD modeling calculations 


\section{Results and Discussions}

Based on the modeling domain defined in Fig. 2 and the operating conditions shown in Table 1, the erosion evaluations for the modeling domain of the SME coil guide were completed. The present analysis used two gap sizes of 0.5 in and 1 in between the lower end of the coil support bar and tank bottom. The velocity in the region of 0.5 in gap was reduced by $\sqrt{2}$ to account for the smaller flow path. The results calculated by the model with an uneven tank floor are compared to those from the observed configurations of the coil guide shown in Fig. 3.

Calculations for three different agitator speeds 65, 103, and $130 \mathrm{rpm}$ were performed. The results of wall shear distributions for two different gap sizes (0.5 in and 1 in gaps) for $130 \mathrm{rpm}$ agitation speed are compared in Fig. 4. For 0.5 in gap distance between tank floor and the lower end of coil support with flat tank bottom, maximum wall shears for four major erosion locations observed by the recent SME inspections and CFD modeling results for SME coil guide are shown in Table 2. Comparison of wall shear distributions for the two different gaps and cavity depths are made in Fig. 5. The same comparison for the lower speed $103 \mathrm{rpm}$ is shown in Fig. 6. The results show that the locations of high erosion sites are not changed when the agitator speed and cavity size are changed. When the erosion patterns are compared between the two different depths (0.35 in and 0.6 in) of eroded cavities, they are not changed significantly as shown in these figures. It is noted that wall shears at the edges of the cavity are much higher than those along the bottom surface of the cavity, and maximum shears of the cavity bottom surface are about the same. Detailed results are summarized in Table 3 and Table 4. These results indicate that the edge regions of the cavity will become smooth, but the shear stress at the bottom of the cavity will decrease to the point of no further erosion.

The vertical velocity inside the cavity is shown in Fig. 7 for an agitator impeller speed of $130 \mathrm{rpm}$. In this figure the downstream regions of the cavity area have the highest velocity magnitudes. Figure 8 presents vorticity distributions near the top plane of the cavity which is the tank floor surface. The figure shows that the boundary region of the eroded area has the highest fluid rotation, which corresponds to the smooth edge of the erosion sites as observed by the recent inspections.

The present analysis is mainly concerned with the erosion estimates for the tank bottom. The results show that serious erosion damages can occur to the tank bottom downstream of the cavity region when the agitator impeller operates continuously at 130 rpm. The sites of high abrasive erosion and the degree of erosion damage on the bottom of the SME for the flow conditions shown in Table 1 are compared in Figs. 5 and 6.

The results demonstrate that when the agitator operates between $65 \mathrm{rpm}$ and $103 \mathrm{rpm}$, the leading edge of the coil guide will be damaged by erosion, but the maximum wall shear for the tank bottom below the coil support is only about $90 \mathrm{~Pa}$. This is well below the value of about $169 \mathrm{~Pa}$ corresponding to serious erosion of the leading-edge component as observed in the recent inspections of the SME vessel coil guide [2]. The present results for several high erosion sites of the cavity model are compared for three different agitator speeds in Table 3. As shown in Table 2 and Table 3, the maximum wall shear locations at the tank bottom are the region below T-shaped coil support (region 1 in Table 2) and the cavity edge on the tank bottom (region 4 in Table 3). The 
shear stress on the bottom surface of the cavity was low in all cases, indicating that the rate at which cavity depths grows will decrease with cavity depth.

As shown in Table 4, the shear stress on the bottom surface of the cavity in Region 1 was low in all cases, indicating that the rate at which cavity depths grows will decrease with cavity depth.

Table 2. Maximum wall shears for four major erosion locations observed by the recent SME inspections and CFD modeling results for SME coil guide (0.5 in gap between tank floor and the lower end of coil support bar with flat tank bottom)

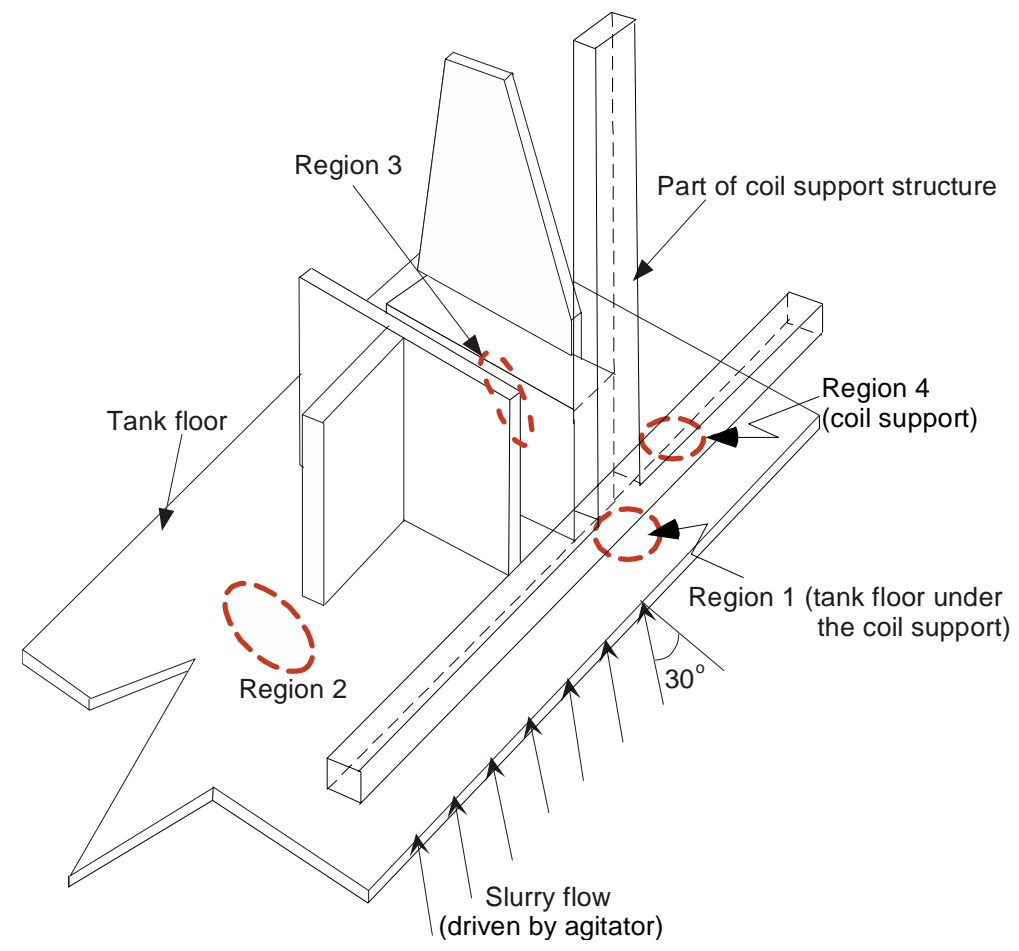

\begin{tabular}{|c|c|c|c|c|}
\hline $\begin{array}{c}\text { Slurry velocity magnitude for } \\
\mathbf{3 0} \text { incident into coil guide } \\
\text { region (agitator speed) }\end{array}$ & $\begin{array}{c}\text { Max. wall } \\
\text { shear at } \\
\text { Region 1 }\end{array}$ & $\begin{array}{c}\text { Max. wall } \\
\text { shear at } \\
\text { Region 2 }\end{array}$ & $\begin{array}{c}\text { Max. wall } \\
\text { shear at } \\
\text { Region 3 }\end{array}$ & $\begin{array}{c}\text { Max. wall } \\
\text { shear at } \\
\text { Region 4 }\end{array}$ \\
\hline $0.65 \mathrm{~m} / \mathrm{sec}(65 \mathrm{rpm})$ & $46 \mathrm{~Pa}$ & $19 \mathrm{~Pa}$ & $28 \mathrm{~Pa}$ & $52 \mathrm{~Pa}$ \\
\hline $1.3 \mathrm{~m} / \mathrm{sec}(103 \mathrm{rpm})$ & $90 \mathrm{~Pa}$ & $45 \mathrm{~Pa}$ & $76 \mathrm{~Pa}$ & $123 \mathrm{~Pa}$ \\
\hline $1.8 \mathrm{~m} / \mathrm{sec}(130 \mathrm{rpm})$ & $169^{\star} \mathrm{Pa}$ & $70 \mathrm{~Pa}$ & $123^{\star *} \mathrm{~Pa}$ & $184^{\star} \mathrm{Pa}$ \\
\hline
\end{tabular}

Note: *Severe damage due to erosion (observed)

** High erosion (observed) 
Table 3. Maximum wall shears for five major erosion locations observed by the recent SME inspections and CFD modeling results for the existing SME coil guide (0.5 in gap between tank floor and the lower end of coil support bar and 0.35 in cavity depth, referring to Fig. 4)

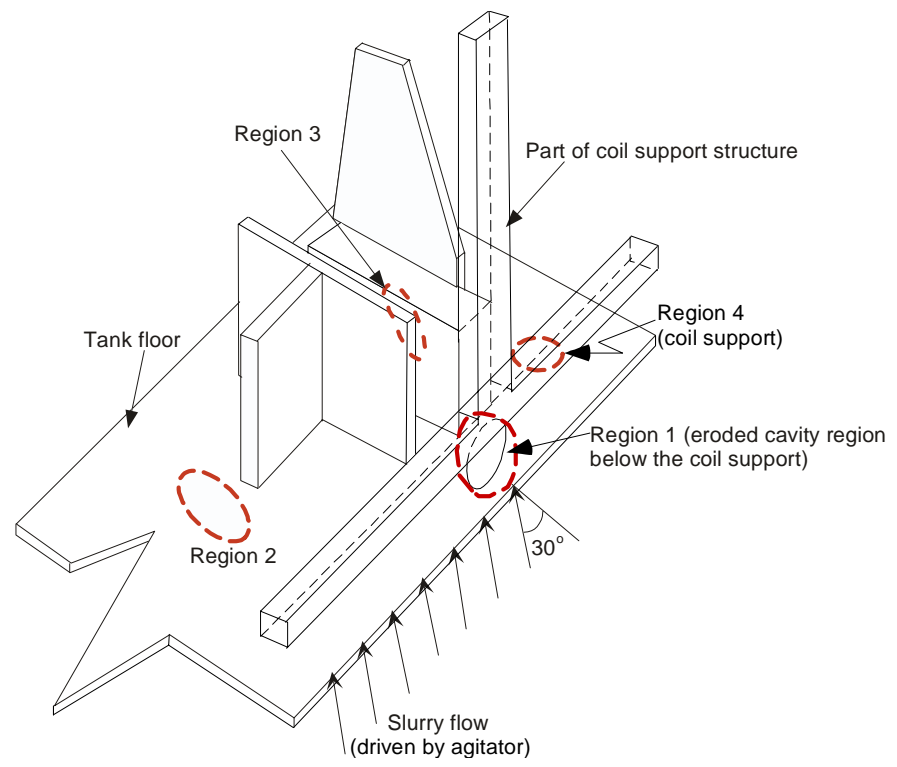

\begin{tabular}{|c|c|c|c|c|c|}
\hline \multirow{2}{*}{$\begin{array}{c}\text { Slurry velocity } \\
\text { magnitude for } 30^{\circ} \\
\text { incident into coil guide } \\
\text { region (agitator speed) }\end{array}$} & \multicolumn{2}{|c|}{$\begin{array}{c}\text { Max. wall shear at } \\
\text { Region } 1\end{array}$} & \multirow{2}{*}{$\begin{array}{l}\text { Max. wall } \\
\text { shear at } \\
\text { Region } 2\end{array}$} & \multirow{2}{*}{$\begin{array}{l}\text { Max. wall } \\
\text { shear at } \\
\text { Region } 3\end{array}$} & \multirow{2}{*}{$\begin{array}{l}\text { Max. wall } \\
\text { shear at } \\
\text { Region } 4\end{array}$} \\
\hline & $\begin{array}{l}\text { Cavity } \\
\text { bottom }\end{array}$ & $\begin{array}{l}\text { Cavity } \\
\text { edge }\end{array}$ & & & \\
\hline $0.65 \mathrm{~m} / \mathrm{sec}(65 \mathrm{rpm})$ & $22 \mathrm{~Pa}$ & $42 \mathrm{~Pa}$ & $19 \mathrm{~Pa}$ & $29 \mathrm{~Pa}$ & $52 \mathrm{~Pa}$ \\
\hline $1.3 \mathrm{~m} / \mathrm{sec}$ (103 rpm) & $40 \mathrm{~Pa}$ & $93 \mathrm{~Pa}$ & $45 \mathrm{~Pa}$ & $76 \mathrm{~Pa}$ & $121 \mathrm{~Pa}$ \\
\hline $1.8 \mathrm{~m} / \mathrm{sec}(130 \mathrm{rpm})$ & $59 \mathrm{~Pa}$ & $140 \mathrm{~Pa}$ & $70 \mathrm{~Pa}$ & $123 \mathrm{~Pa}$ & $180 \mathrm{~Pa}$ \\
\hline
\end{tabular}

Table 4. Maximum wall shears at the bottoms of two different cavity sizes on the SME tank floor and two different gap sizes for $130 \mathrm{rpm}$ operating conditions

\begin{tabular}{|c|c|c|c|c|}
\hline $\begin{array}{c}\text { Gap size between coil } \\
\text { support tab and tank floor }\end{array}$ & \multicolumn{2}{|c|}{ I in gap } & \multicolumn{2}{c|}{0.5 in gap } \\
\hline Cavity depth on tank floor & 0.35 in deep & 0.6 in deep* & 0.35 in deep & 0.6 in deep* \\
\hline $\begin{array}{c}\text { Max. wall shear at cavity } \\
\text { bottom }\end{array}$ & $56 \mathrm{~Pa}$ & $55 \mathrm{~Pa}$ & $59 \mathrm{~Pa}$ & $57 \mathrm{~Pa}$ \\
\hline
\end{tabular}

Note:*This size was used only for sensitivity calculations, but it has not been observed by the visual inspection. 
Date: $\quad 3 / 2 / 2004$

Page: $\quad 8$ of 14
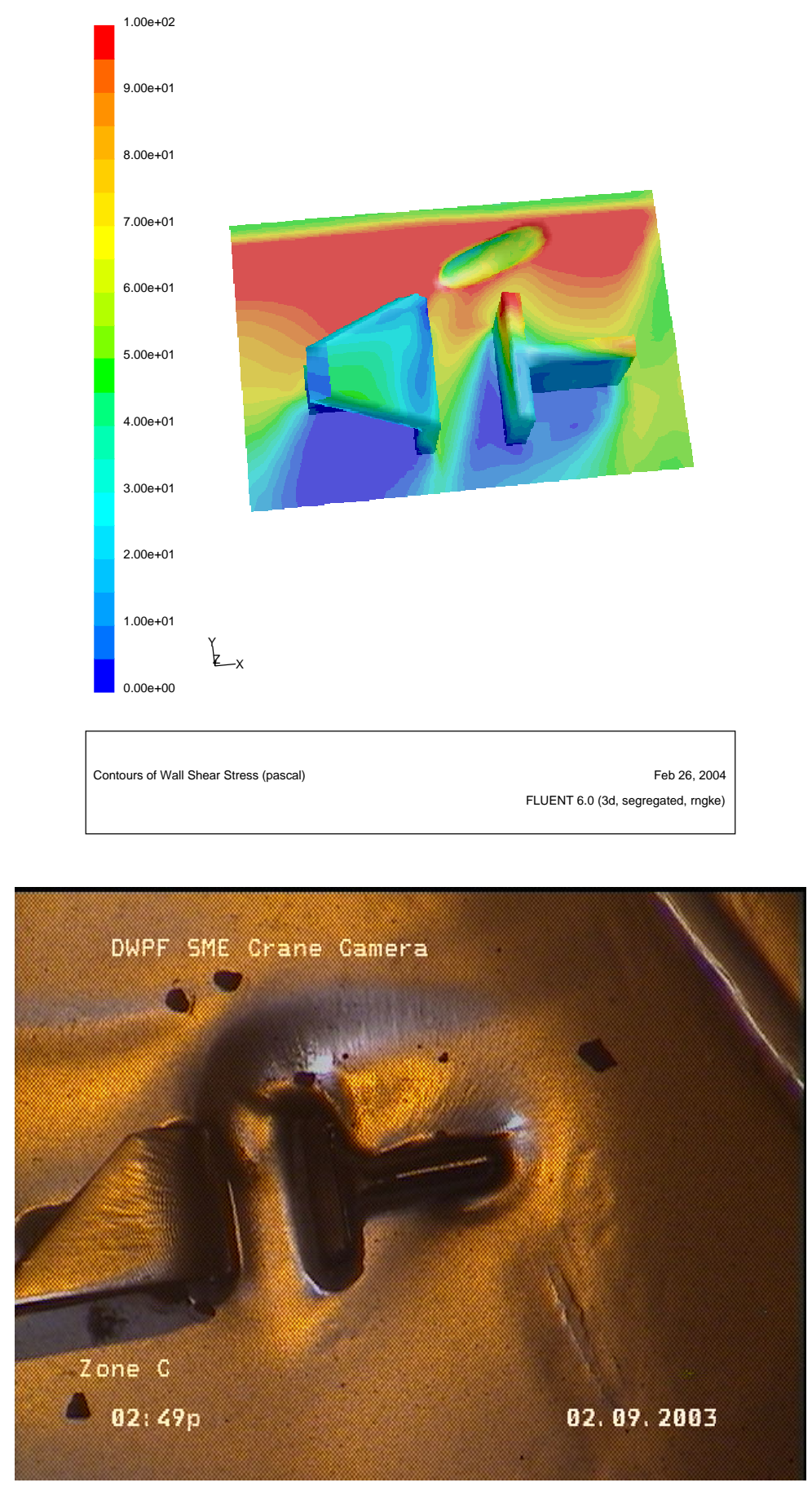

Figure 3. Comparison of the predicted high wall shear indicated on the right lead-in plate (above) to the worn-away lead-in plate shown in the visual inspection photo (below) (the model predictions based on $130 \mathrm{rpm}(1.8 \mathrm{~m} / \mathrm{sec})$ and $30^{\circ}$ flow incidence) 


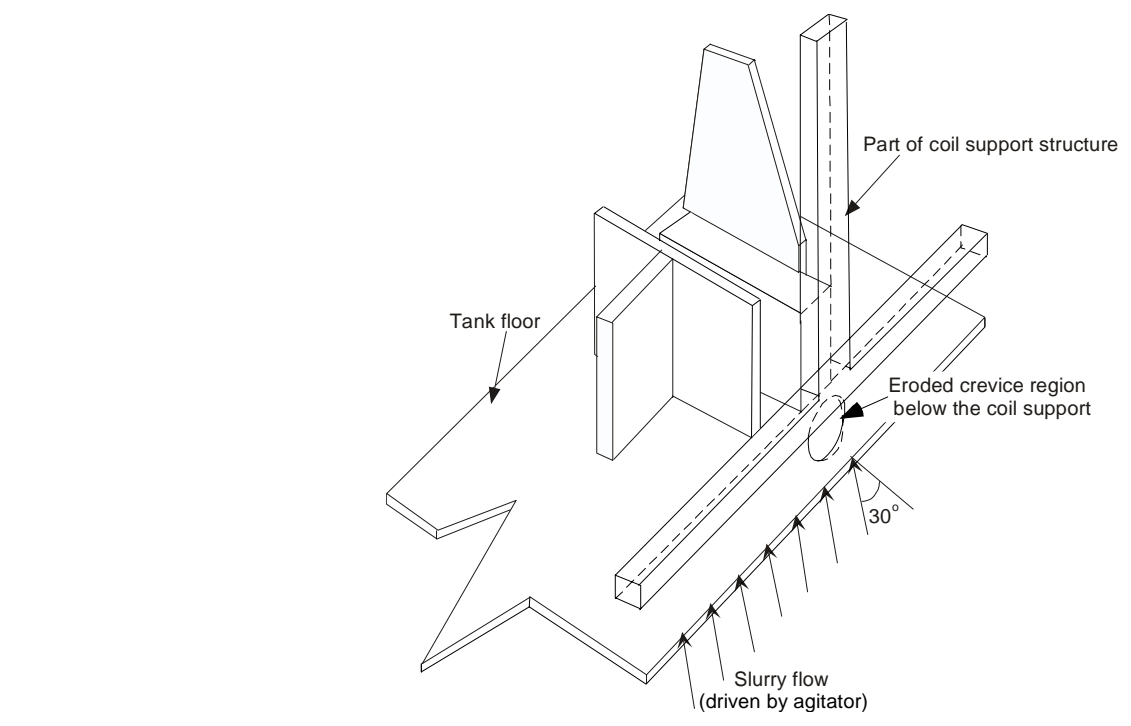

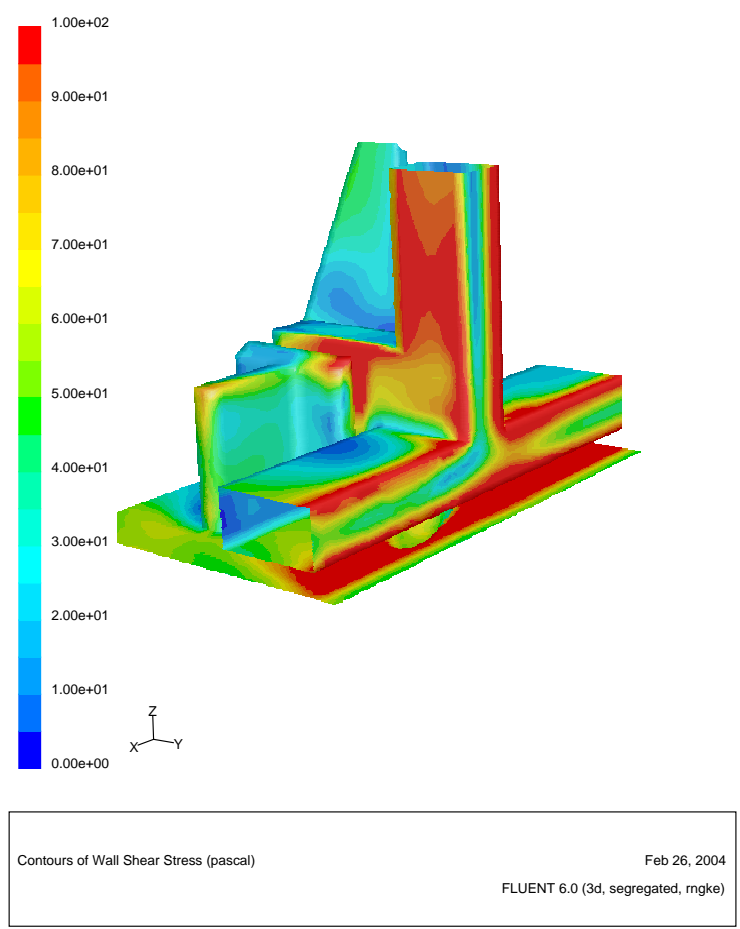

(0.5 in gap)

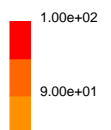

$800+01$
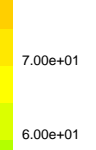

$6.00 e+01$
$5.00 e+01$

$4.00 \mathrm{e}+01$

$3.00 \mathrm{e}+01$

$2.00 \mathrm{e}+01$

${ }_{0.00 e+00}^{1.00 e+01} \times L_{Y}$
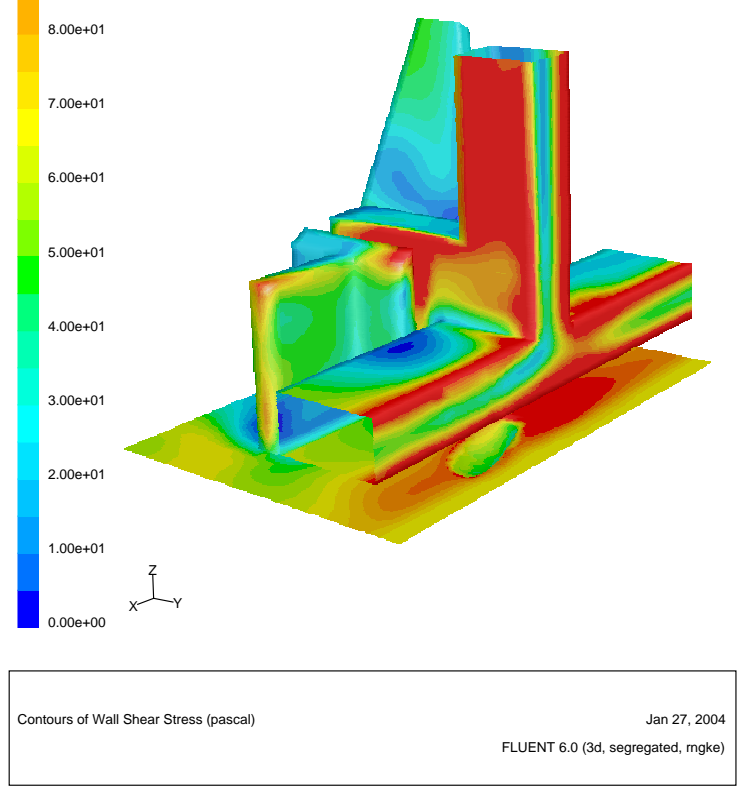

(1 in gap)

Figure 4. Wall shear comparison of the SME/MFT coil support structures with the eroded tank bottoms for two different gap sizes between the tank bottom and the lower end of coil support under 130 rpm agitator operation 

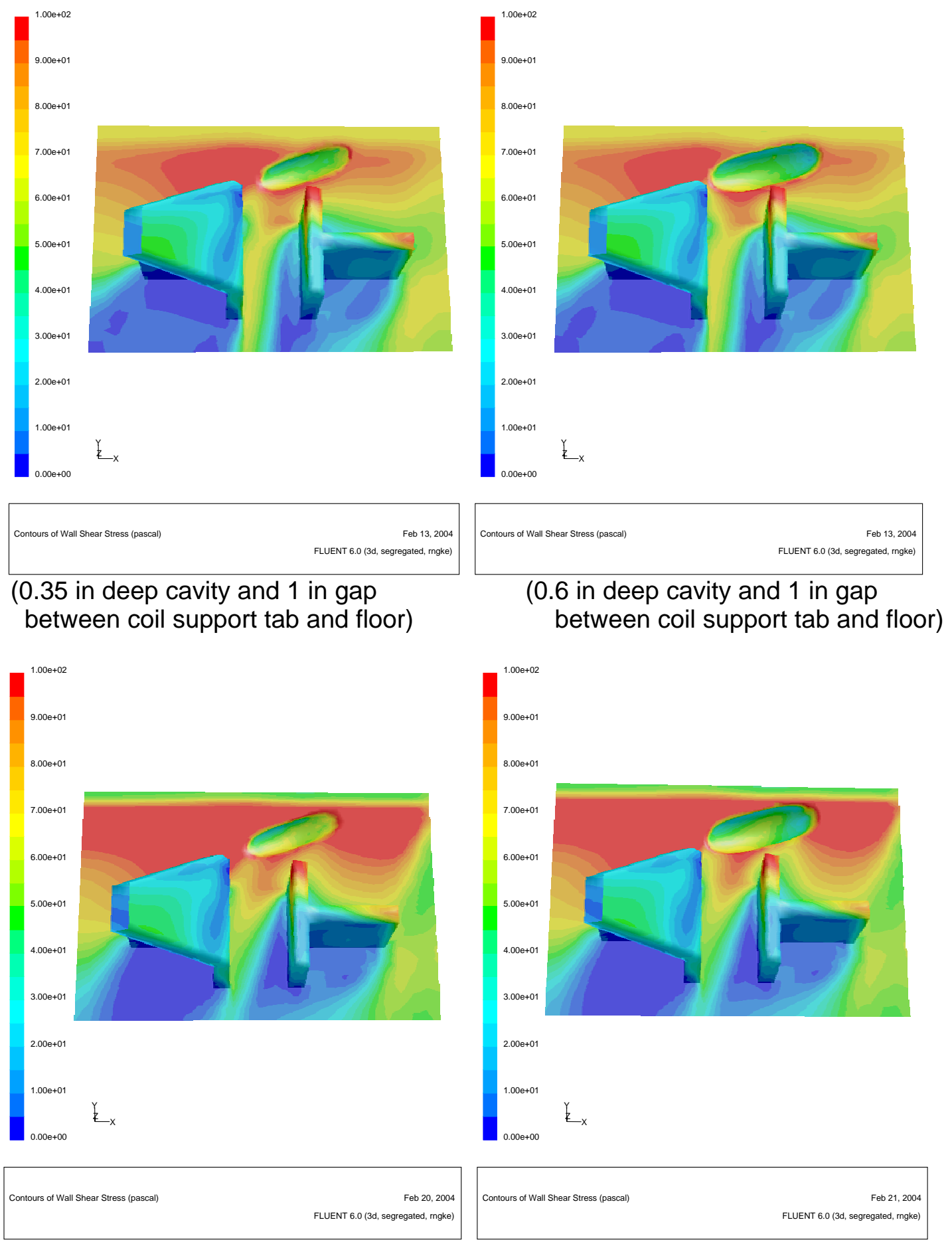

(0.35 in deep cavity and 0.5 in gap between coil support tab and floor)

(0.6 in deep cavity and 0.5 in gap between coil support tab and floor

Figure 5. Comparison of wall shear distributions for various gap and cavity sizes under 130 rpm agitator operation 

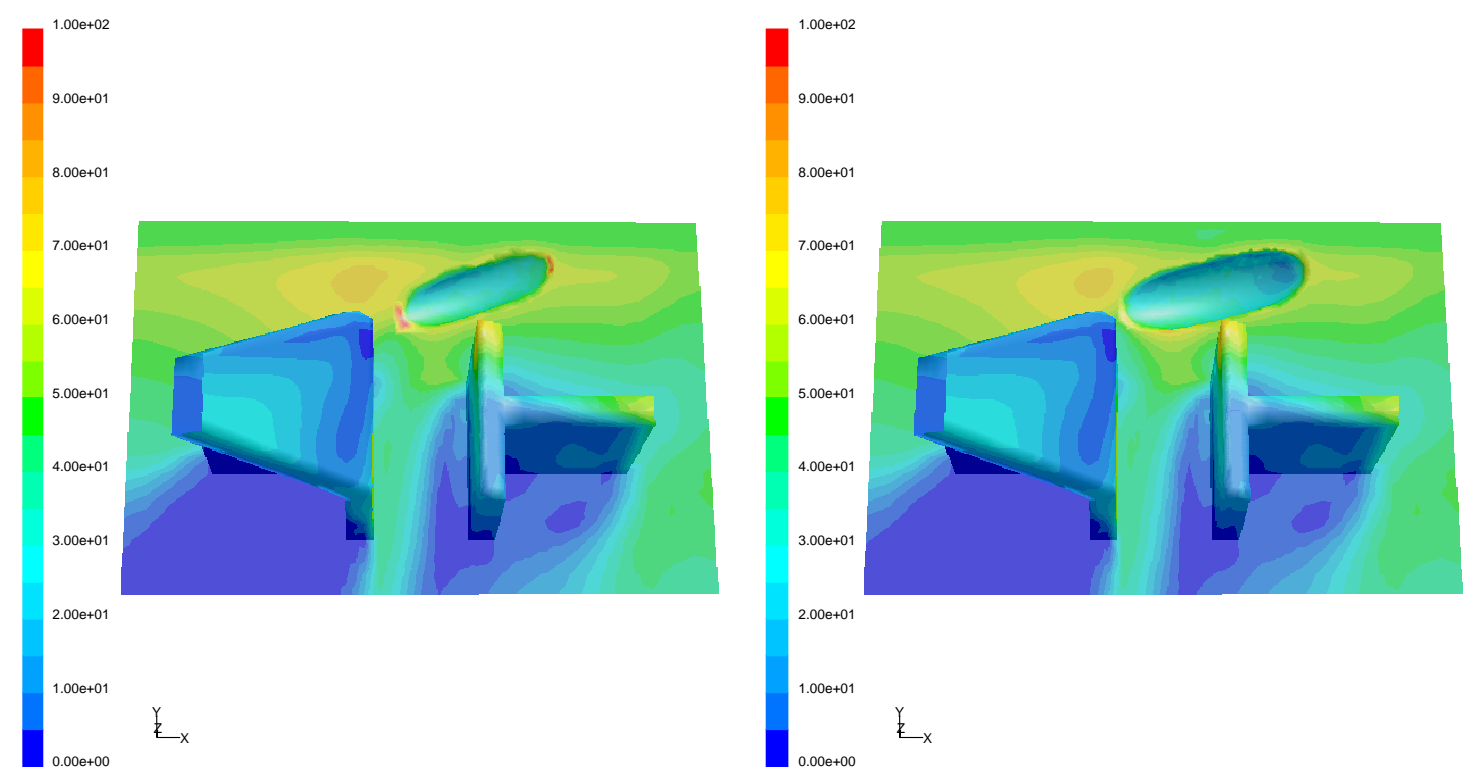

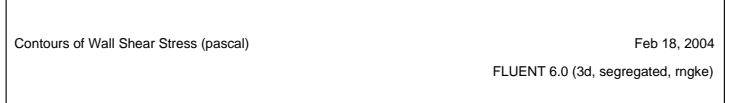

(0.35 in deep cavity and 1 in gap between coil support tab and floor)
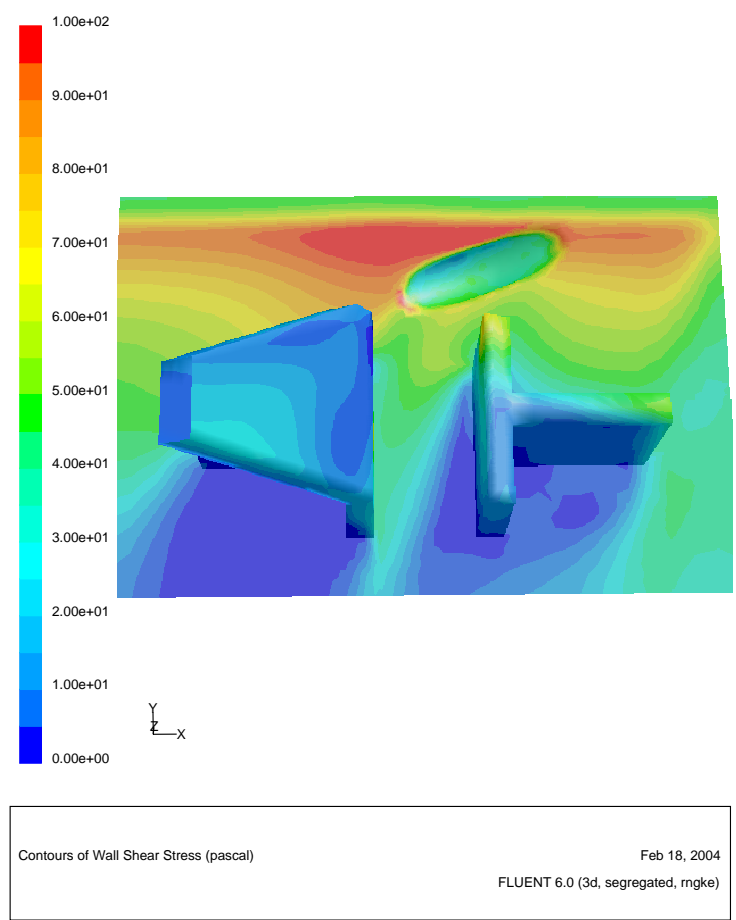

(0.35 in deep cavity and 0.5 in gap between coil support tab and floor)

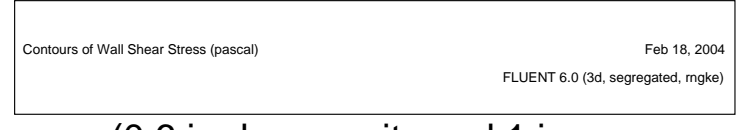

(0.6 in deep cavity and 1 in gap between coil support tab and floor)

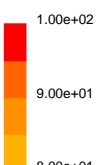

$8.00 \mathrm{e}+01$

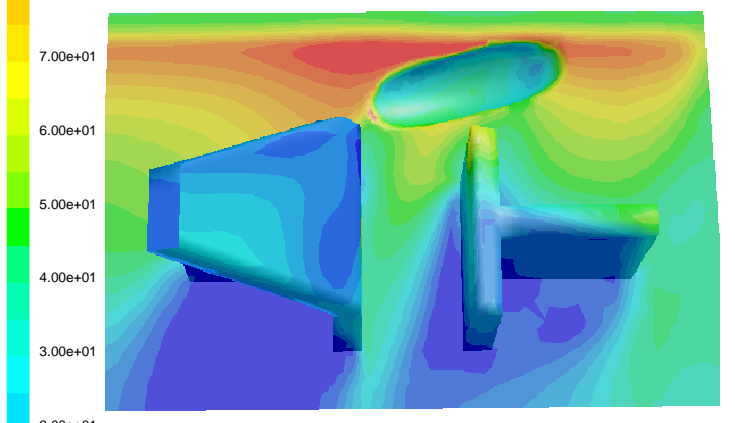

$2.00+01$

$1.00 \mathrm{e}+01$

$\sum_{x}$

(0.6 in deep cavity and 0.5 in gap between coil support tab and floor

Figure 6. Comparison of wall shear distributions between the modified tank bottom and the eroded tank bottom for $103 \mathrm{rpm}$ agitator operation 

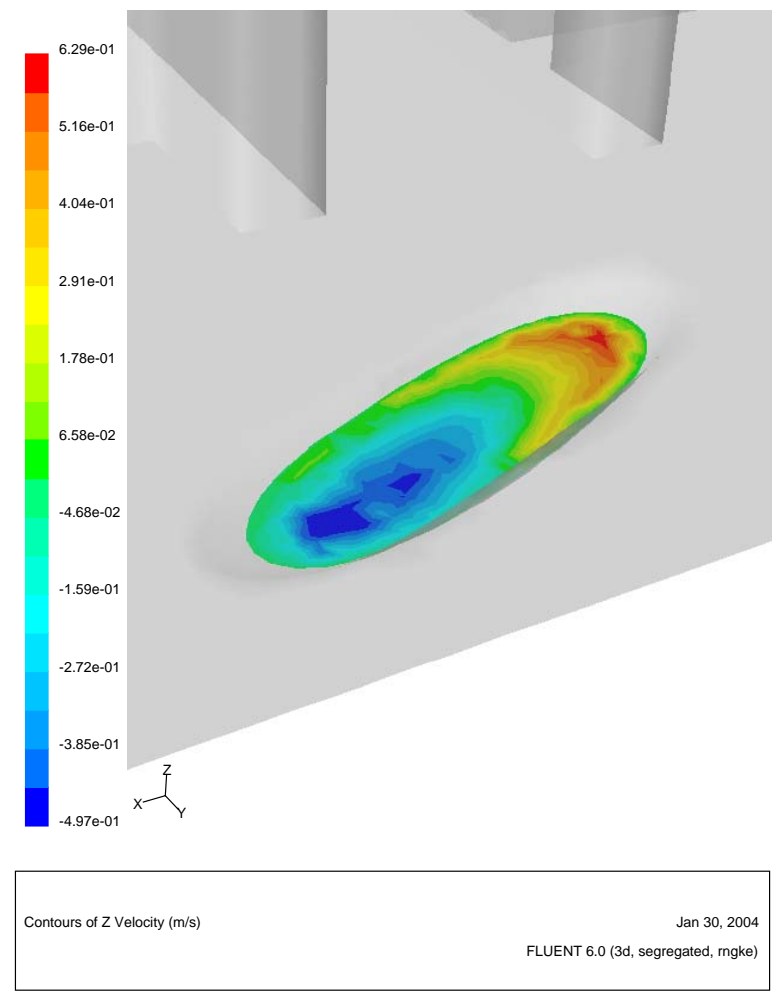

Figure 7. Vertical flow contour inside the eroded cavity region (The blue region is the downward and the red region is upward)

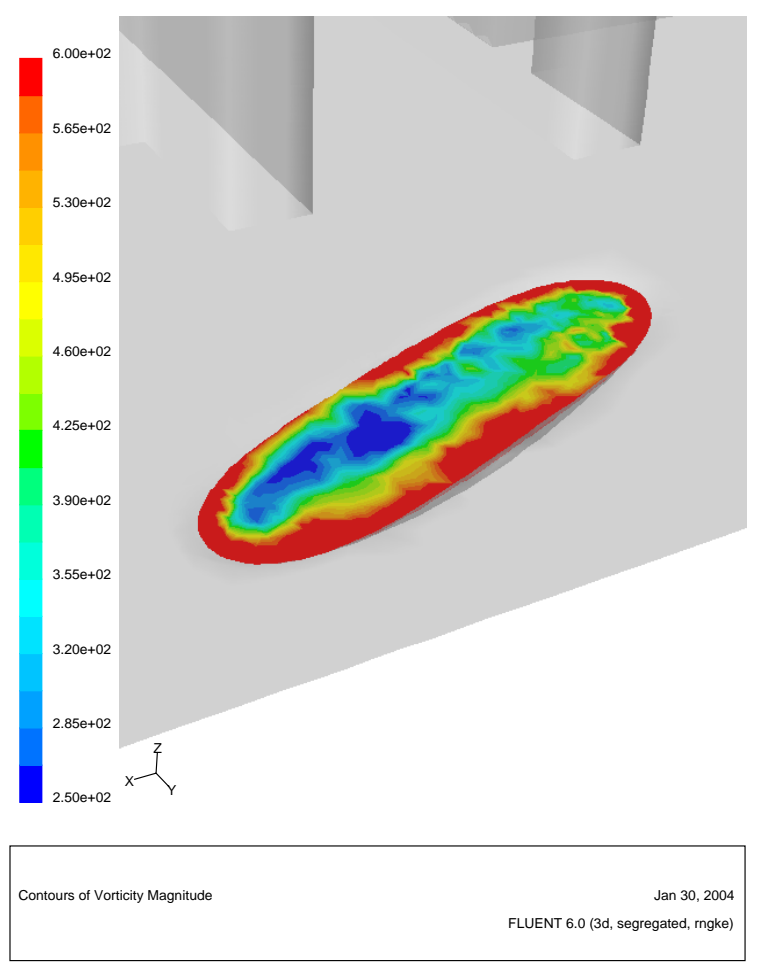

Figure 8. Vorticity distributions near the top plane of the eroded cavity region 


\section{Summary and Conclusions}

The method established in the previous work $[2,3]$ was used to evaluate the potential for erosion in the SME. The computational results from the erosion study were compared to measured erosion in the SME to estimate the potential for continued erosion. The results show:

1. The erosion rate at the bottom of the deepest observed cavities on the SME tank bottom has decreased to an extent that continued erosion will be insignificant. Therefore, no erosion deeper than the currently observed 0.35 in is expected.

2. If agitator speeds are not reduced, the existing eroded cavities will expand horizontally because of high shear stresses at the upper edges of the cavity.

3. If agitator speed is reduced to $103 \mathrm{rpm}$ or lower, shear stresses throughout the tank are reduced enough to preclude significant erosion. Only minor wear is predicted along the edges of the existing eroded cavities on the tank bottom.

4. The results of this report are consistent with previous results detailed in references [2, 3] that were based on the tank geometry. The locations with the highest erosion are at the leading edge of the guide (Region 3 in Table 3), the tank bottom surface at the downstream edge of the eroded cavity region below the coil support, the tank bottom next to the cavity region, the coil guide support, and the upstream lead-in plate.

5. The modeling predictions for high erosion sites on the coil guide are similar to the observed sites in the recent inspections of the SME vessel done by DWPF Engineering. 


\section{References}

1. J. R. Neuville, G. A. Taylor, R. A. Dimenna, and S. Y. Lee, "MFT/SME CFD Modeling", Interoffice Memorandum, CBU-WSE-2003-00111, June 9, 2003.

2. S. Y. Lee, R. A. Dimenna, J. R. Neuville, and G. A. Taylor, "Erosion Modeling Analysis for Modified DWPF SME Tank", WSRC-TR-2003-00534, December 2003.

3. S. Y. Lee, R. A. Dimenna, J. R. Neuville, and G. A. Taylor, "Erosion Modeling Analysis for DWPF MFT/SME Tanks", WSRC-TR-2003-00435, September 2003.

4. S. Y. Lee and R. A. Dimenna, "Erosion Analysis for the Misaligned U2 Nozzle and Its Connector Block", WSRC-TR-2002-00352, April 2002.

5. S. L. Tibrea, C.T, Chandler, C.F. Jenkins, S.Y. Lee, A. P. Rangus, S. L. West, Independent Review of the Slurry Mix Evaporator Repairs, CBU-WSE-2003-0050, March 2003.

6. MixSim 2.0 User's Guide, Fluent, Inc., Lebanon, New Hampshire, 2003.

7. FLUENT, Fluent, Inc., Lebanon, New Hampshire, 1998.

8. H. Schlichting, Boundary Layer Theory, McGraw-Hill Book Company, New York, 1967.

9. Reference Bechtel Drawing No. W752139 (Bumper Guides for Coil Supports), Bechtel/E. I. Dupont De NeMours \& Co. for U.S. Dept. of Energy, Savannah River Plant, South Carolina.

10. W.R. Hinz, Nondestructive Examination Condition Report, SRT-MTS-2003-60109, February 13, 2003.

11. W. M. Kays and M. E. Crawford, Convective Heat and Mass Transfer, Second Edition, McGraw-Hill Book Company, New York, 1980.

12. L. Johnson, SME Tank Coil Guide Insert, M-DCF-S-02056, January 14, 2003. 